\title{
낙하충격실험에 의한 일탈방호시설의 내충격성 평가 Evaluation of Impact Resistance for Derailment Containment Provision Using Drop Weight Test
}

\author{
김남혁* . 강윤석** . 배현웅*** . 김경주**** . 임남형***** \\ Kim, NamHyuk*, Kang, YunSuk**, Bae, HyunUng ${ }^{* * *}$, Kim, KyungJu****, and Lim, NamHyoung ${ }^{* * * *}$
}

\begin{abstract}
In Korea, to prepare for unexpected accidents caused by human errors and natural disasters that cannot be completely prevented, a protective wall (a type of side-structure) against derailed trains has been installed on high-speed railway bridges as one of the physical measures to mitigate the associated damage. However, taking the geometric aspects of a domestic railway bridge's super structure into consideration, such a protective wall is not appropriate, and the corresponding protective performance does not provide adequate security. Hence, a protective wall named Derailment Containment Provision (DCP) was newly developed and installed in the track gauge. In this study, to evaluate the impact resistance of the newly developed DCP, a drop weight experiment was conducted, and the impact behavior corresponding to a specific impact energy was analyzed.
\end{abstract}

Key words : Derailed Train, Derailment Containment Provision, Impact Energy, Drop Weight Test

\section{요 지}

국내 철도에서는 완벽하게 차단할 수 없는 인적 - 자연적 재해 등의 예기치 못한 사고에 대비하여 그 피해를 경감/최소화하기 위한 물리적 수단 중 하나로서 탈선열차에 대한 방호벽을 고속철도 교량상에 설치해왔다. 그러나 국내 교량 상부구조의 기하조건 상 측면구조물 방식의 방호벽은 시뮬레이션 해석상 방호성능이 충분하지 않아 일탈방호시설(Derailment Containment Provisions, DCP)을 개발하게 되었다. 본 논문에서는 개발된 궤간 내 일탈방호시설의 내충격성 평가를 위해 실험체를 제작하여 중량체 낙하충격실험을 수행하였으며 소정의 충돌에너지에 대한 거동을 분석하였다.

핵심용어 : 탈선열차, 일탈방호시설, 충돌에너지, 낙하충격실험

\section{1. 서 론}

철도사고 중 열차의 탈선/충돌 사고는 발생빈도가 낮으나 발생하면 그 피해정도가 상당히 큰 대형사고로 이어질 수 있어 철도운영기관 및 유관기관에서는 제도적 · 시스템적으
로 관리를 철저히 하고 있다. 원천적으로 탈선/충돌이 발생되 지 않도록 예방하는 것이 가장 이상적인 대비이나, 완벽하게 차단할 수 없는 인적 - 자연적 재해 등의 예기치 못한 사고에 대비하여 그 피해를 경감/최소화하기 위한 물리적 수단을 강구할 필요성이 있다(Bae, 2015; Bae et al., 2018a; Kim

*정회원, ${ }^{1}$ 한국철도공사 선로관리처 처장

2 충남대학교 토목공학과 박사과정(E-mail: rlaskagur@korail.com)

Member, ${ }^{l}$ Head of Track Management Office, Korea Railroad

${ }^{2}$ Ph.D. Candidate, Department of Civil Engineering, Chungnam National University

**정회원, 한국철도기술연구원 철도구조연구팀 책임연구원

Member, Ph.D., Head Researcher, Structural Research Team, Korea Railroad Research Institute

***정회원, 로드키네마틱스 기업부설연구소 선임연구원

Member, Ph.D., Senior Researcher, R\&D Center, Road Kinematics co., Ltd.

****로드키네마틱스 대표이사

Ph.D., President, Road Kinematics co., Ltd.

*****교신저자, 정회원, 충남대학교 토목공학과 교수(Tel: +82-42-821-7005, Fax: +82-42-825-0318, E-mail: nhrim@cnu.ac.kr)

Corresponding Author, Member, Professor, Department of Civil Engineering, Chungnam National University 
et al., 2018). 일반적으로 국내 일반철도 및 도시철도에서는 급곡선부, 교량, 분기기 등의 위험개소에 탈선방지가드레일 을 설치함으로써 탈선사고에 대비하고 있으며, 고속철도에 서는 교량구간에 한하여 방호벽을 설치하도록 하고 있다 (KR, 2016, 2017; Railroad Safety Act, 2018). 유럽 각국에서 는 열차의 탈선 발생 후 피해 확대를 최소화하기 위한 대책으 로 3가지 유형의 물리적 시설물(Derailment Containment Provisions, DCP)을 적용하고 있다(Booz Allen Hamilton Inc., 2004). 국내의 교상가드레일과 같이 궤간 내에 설치하여 탈선된 차륜과 충돌하도록 하는 유형(DCP type 1), 궤간 외측에 설치하여 탈선된 차륜과 충돌하도록 하는 유형(DCP type 2), 궤간 외측에 설치하여 탈선된 열차의 차축/대차와 충돌하도록 하는 유형(DCP type 3)이 있다(Fig. 1).
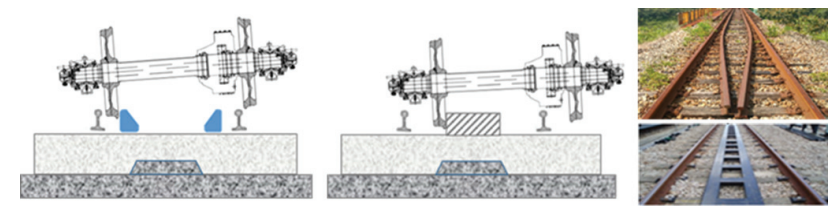

(a) DCP Type 1
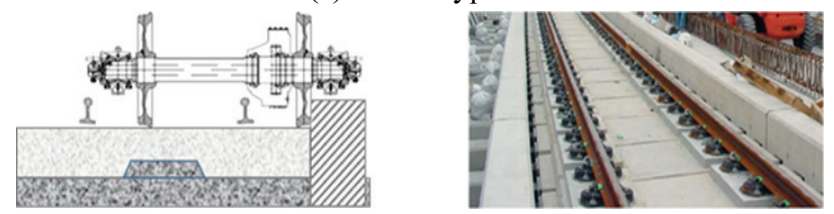

(b) DCP Type 2
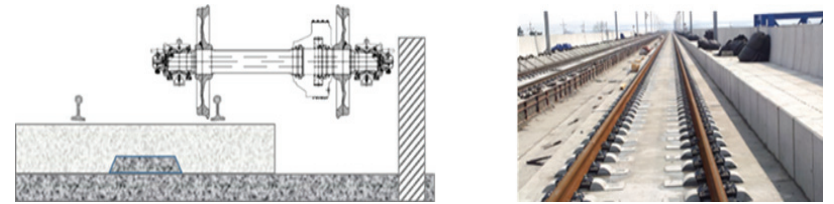

(c) DCP Type 3

Fig. 1. Type of Derailment Containment Provisions (DCP)

현재 국내의 고속철도(운행속도 $200 \mathrm{~km} / \mathrm{h}$ 이상) 교량상에 일률적으로 설치되고 있는 방호벽(DCP type 3 과 유사)은 2004년 국내 고속철도 도입 시 유럽 형태를 반영하여 도입하 였다. 그러나 이에 대한 설계하중 및 설치위치, 규격에 대한 기준이 정립되어 있지 않아 국내 실정을 고려한 합리적이고 효율적인 방호시설 개발 연구가 수행되었다(KAIA, 2020). 이 연구에서는 국내 교량 상부구조의 기하조건 상(상판폭 최적화) 측면구조물 방식의 탈선방호벽(DCP type 3)은 매우 큰 내충격성을 갖는 단면구조 설계가 되어야 하고 비효율적 인 시설물이 될 수 있어, 궤간 내에서 탈선된 열차 차륜의 횡방향 이동을 제어해주는(DCP type 1) 효율적인 구조의 일탈방호시설이 제안되었다(Bae et al., 2018b; Yi et al., 2018; Kim et al., 2019).

Fig. 2는 국내에서 개발된 탈선열차의 과도한 일탈(Lateral Deviation)을 차륜제어에 의해 막는 일탈방호시설(이하 DCP 로 지칭) 개념도로, 궤간 내에 설치된 콘크리트 블록이 탈선
된 열차의 횡방향 이동 거리를 최소화하여 구조물에 작용하 는 충돌에너지를 현저히 감소시키고 단선의 경우 궤도 양측 에 설치해야 하는 측면구조물 방식과 달리 단일 구조로 설치할 수 있는 효율성 및 경제성을 확보한 시설물이다. 선행연구를 통해 개발된 궤간 내 $\mathrm{DCP}$ 의 구조설계를 위한 해석적 거동 검토(Yi et al., 2018) 및 구조적 성능을 검증하기 위한 실내 정적실험(Kim et al., 2019)이 수행되었으며, DCP 는 탈선된 열차 차륜의 동적 충돌하중을 받는 구조물이므로 내충격 성능 평가 또한 필요하다.
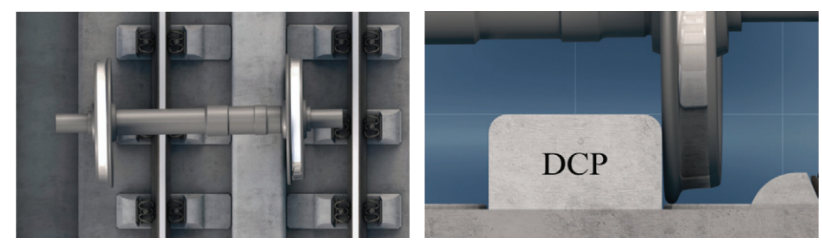

Fig. 2. DCP within Track Gauge

본 논문에서는 개발된 궤간 내 DCP 실험체에 소정의 충돌에너지를 가하기 위하여 중량체 낙하충격실험(Drop Weight Test)을 수행하였으며 이를 통해 충격력에 대한 거동 을 분석하고 내충격성 평가 연구를 수행하였다.

\section{2. 실험 개요 및 방법}

\section{1 궤간 내 DCP 실험체}

개발된 궤간 내 DCP는 현재 운용 중인 콘크리트 궤도에 적용을 목적으로 프리캐스트 콘크리트 패널로 제작되며(Fig. $3)$, 열차 탈선 시 차륜의 DCP 충돌로 인해 Track Concrete Layer (TCL)층에 전달되는 하중 시스템을 고려하여 DCP와 $\mathrm{TCL}$ 층간의 접합은 앵커, 케미컬앵커, 무수축 모르타르를 이용하여 제작하였다. $\mathrm{DCP}$ 패널의 길이는 $2,280 \mathrm{~mm}$, 너비 $500 \mathrm{~mm}$, 두께 $125 \mathrm{~mm}$ 이며, TCL층은 실제 교량상 콘크리트 궤도와 동일한 두께 $250 \mathrm{~mm}$ 를 적용하고 운반과 실험환경을 고려하여 길이 $3,000 \mathrm{~mm}$, 너비 $1,000 \mathrm{~mm}$ 로 제작하였다. DCP-TCL 결합 실험체의 제원은 Fig. 4 와 같다(Kim et al., 2019).

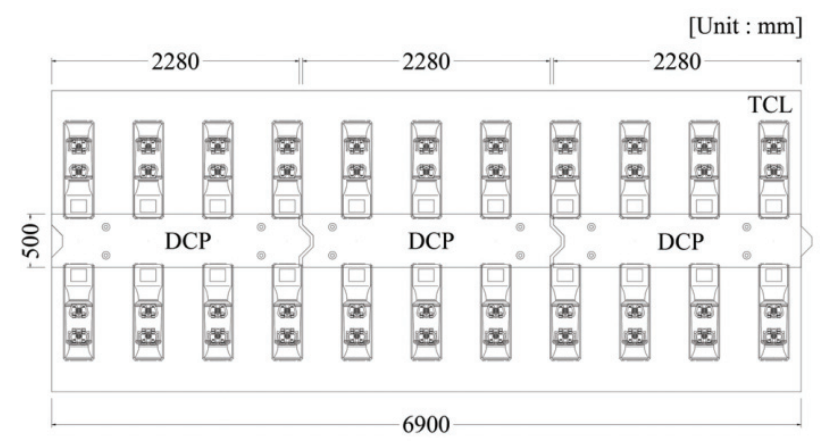

Fig. 3. DCP on Concrete Track 


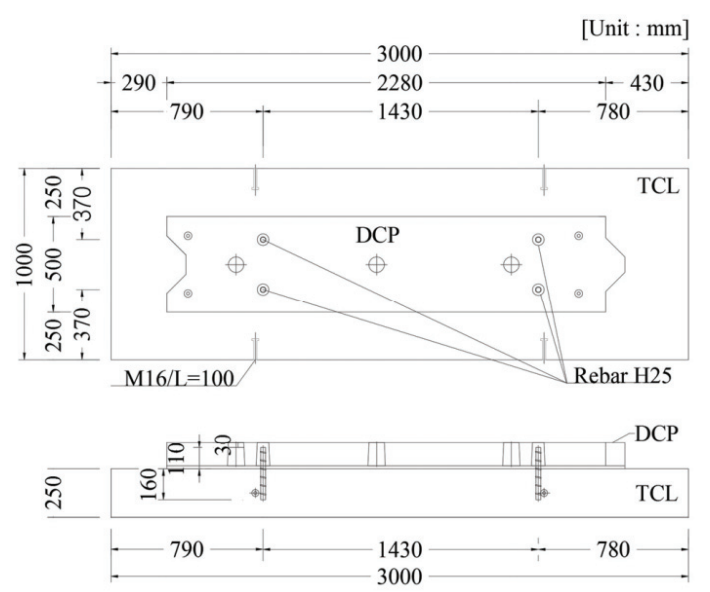

Fig. 4. Dimensions of DCP-TCL Test Specimen

$\mathrm{DCP}$ 는 TCL층에 $\mathrm{H} 25$ 앵커 4개를 이용하여 고정될 수 있도록 설계 - 제작되었으며, $\mathrm{DCP}$ 와 TCL층의 앵커 매입 깊이는 각각 $110 \mathrm{~mm}, 160 \mathrm{~mm}$ 이고 $\mathrm{DCP}$ 와 TCL 콘크리트 의 설계압축강도 $\left(f_{c k}\right)$ 는 각각 $35 \mathrm{MPa}, 30 \mathrm{MPa}$ 이다. $\mathrm{DCP}$ 와 $\mathrm{TCL}$ 은 결합 시 $\mathrm{DCP}$ 하부 충진재로 유동성 및 동절기 조기 강도 발현, 수축량과 충진층 $15 \mathrm{~mm}$ 를 고려하여 무수 축그라우트 $(28$ 일 압축강도 $60 \mathrm{MPa})$ 를 적용하였다. 후설치 앵커 시공에는 고강도 이형철근 $(\mathrm{H} 25, \mathrm{SD} 400)$ 과 케미컬앵 커를 사용하였다(Kim et al., 2019).

\section{2 실험 방법}

실험에 사용된 낙하충격실험기(Drop Tower)는 0.4 0.7 tonf의 낙하 중량체(충돌부)를 설치할 수 있으며, 낙하높이 는 최대 5 6 m로 25 35 kJ의 위치에너지를 재하할 수 있다 (Fig. 5).

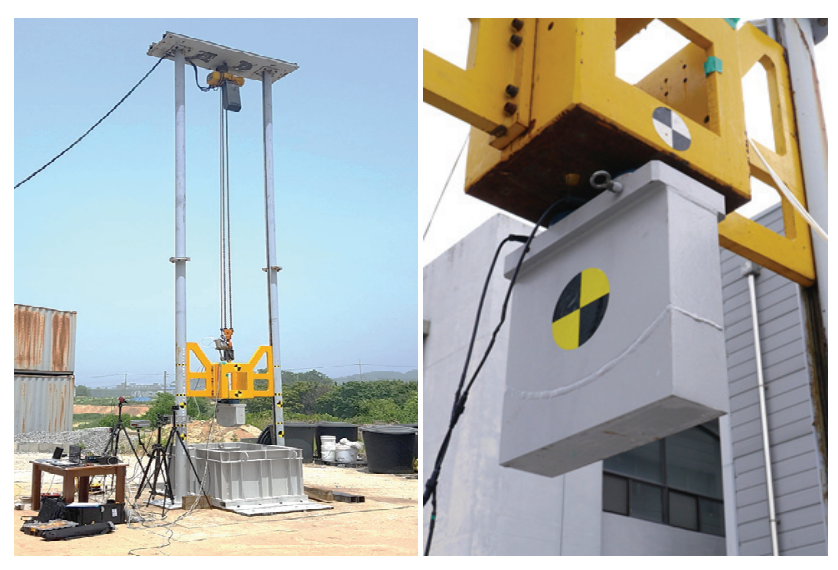

(a) Drop Tower

(b) Weight (Head)

Fig. 5. Drop Tower and Weight

궤간 내 DCP에 가해지는 충돌하중은 Fig. 6 과 같이 탈선열 차 차륜의 내측 면이 DCP 측면(높이 $140 \mathrm{~mm}=\mathrm{DCP}$ 두께 $125 \mathrm{~mm}$ + 그라우트 채움 $15 \mathrm{~mm}$ )과 접촉하여 작용한다.

실제 탈선 시에는 원형 차륜 내측의 일부 면적이 접촉하나 본 실험에서 낙하 중량체의 충돌부 $(\mathrm{Head})$ 접촉면적을 제작 상 편의를 고려하여 직사각형으로 가정하여 제작하였다 (Figs. 5(b) and 6(b)).

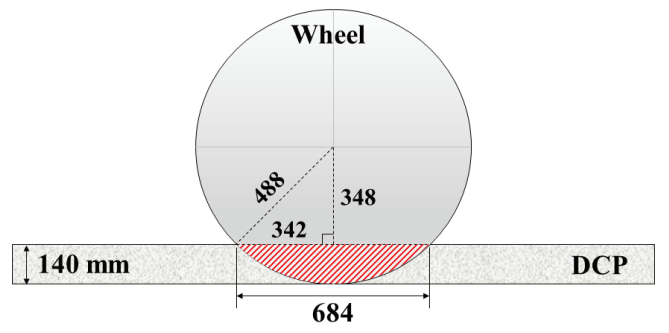

(a) Geometrical Contact Area

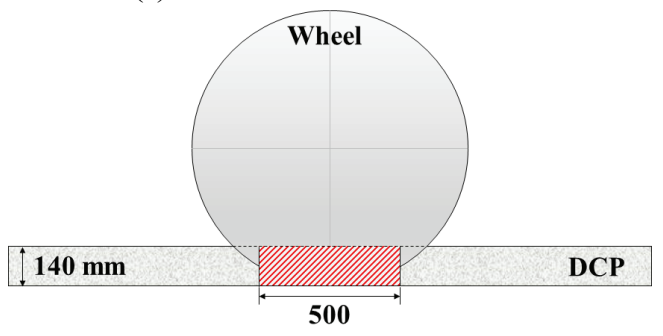

(b) Simplified Contact Area

Fig. 6. Impact Contact Area between DCP and Wheel

중량체는 총 $718 \mathrm{~kg}$ 의 질량으로 자유 낙하시켜 중력에 의해 위치에너지가 운동에너지로 변환되는 것을 이용하여 실험체를 가격한다. 그리고 중량체의 충돌지점은 Fig. 7과 같이 DCP 길이 방향으로 양쪽 앵커 사이의 중앙부와 한쪽의 앵커부 두 가지 경우로 설정하였다. 거치된 DCP-TCL 결합 실험체가 충돌 시에 바닥과 분리되거나 전도되지 않도록 단단히 고정하였다.

\section{$\downarrow$}

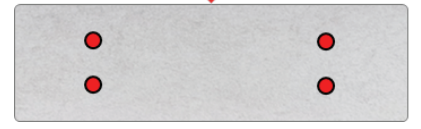

Fig. 7. Impact Point of Test Specimen

실험에서 충격에너지는 낙하 중량체의 질량과 낙하 높이 를 이용하여 이론적으로 계산할 수 있으며, 보조적으로 초당 1,000 프레임 $(1,000 \mathrm{fps})$ 의 촬영이 가능한 고속카메라를 사용 하여 영상 Tracking 분석을 통해 낙하 중량체 및 DCP 실험체 의 거동을 분석하고자 하였다.

\section{3. 실험결과 및 분석}

\section{1 실험 CASE}

총 3 개의 $\mathrm{DCP}$ 실험체를 제작하여 7 개 $\mathrm{CASE}$ 의 실험을 수행하였다. CASE 1은 낙하 높이 $0.5 \mathrm{~m}$ 에서 앵커부에 충돌 
하는 조건이며, CASE 2 7은 중앙부에 충돌하는 조건으로 낙하 높이를 달리함으로써 충격에너지를 누적시켜 $\mathrm{DCP}$ 의 손상상태를 파악하고자 하였다. Table 1에 실험 CASE 별 낙하 높이와 이론적 위치에너지를 정리하였다.

Table 1. Test Case

\begin{tabular}{c|c|c|c|c}
\hline Specimen & $\begin{array}{c}\text { Case } \\
\text { No. }\end{array}$ & $\begin{array}{c}\text { Impact } \\
\text { Point }\end{array}$ & $\begin{array}{c}\text { Drop Height } \\
(\mathrm{m})\end{array}$ & $\begin{array}{c}\text { Potential } \\
\text { Energy (kJ) }\end{array}$ \\
\hline$\# 1$ & 1 & Anchor & 0.50 & 3.52 \\
\hline \multirow{3}{*}{$\# 2$} & 2 & Center & 0.50 & 3.52 \\
\cline { 2 - 5 } & 3 & Center & 1.00 & 7.04 \\
\cline { 2 - 5 } & 4 & Center & 0.50 & 3.52 \\
\hline \multirow{3}{*}{$\# 3$} & 5 & Center & 1.00 & 7.04 \\
\cline { 2 - 5 } & 6 & Center & 1.00 & 7.04 \\
\cline { 2 - 5 } & 7 & Center & 2.14 & 15.07 \\
\hline
\end{tabular}

\section{2 결과 분석}

\subsubsection{CASE $1(\# 1-1)$}

실측된 낙하 높이는 $0.508 \mathrm{~m}$ 로 $\mathrm{DCP}$ 실험체의 한쪽 앵커 부에 작용시킨 충돌에너지는 $3.58 \mathrm{~kJ}$ 이다. 충돌부 표면에 균열이 발생되었으며 TCL층과 $\mathrm{DCP}$ 패널 간 접합부 사이 (그라우트)에 약 $1 \mathrm{~mm}$ 의 미세한 분리 현상이 발생되었다 (Fig. 8). 그러나 충돌하지 않은 반대쪽 앵커부에서는 균열 및 분리 현상이 나타나지 않았으며, DCP 패널을 지지하는 앵커가 모두 건전한 상태로 DCP의 목적상 탈선된 차륜의 횡방향 이동을 제어하는 기능을 상실한 정도의 상태는 아니다.
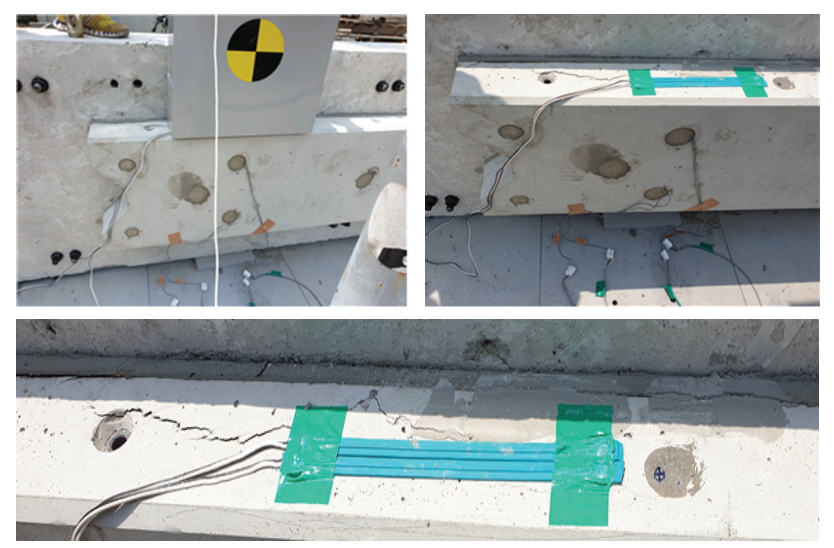

Fig. 8. Condition after Test (CASE 1)

Fig. 9는 시간에 따른 중량체의 낙하속도를 고속카메라 영상 Tracking 분석에 의해 나타낸 것으로 DCP와 충돌(0.00 $\mathrm{sec}$ ) 직전의 속도가 $3.02 \mathrm{~m} / \mathrm{sec}$ 로 측정되었다. 낙하 높이 $(0.508 \mathrm{~m})$ 에 따른 이론 속도 $3.16 \mathrm{~m} / \mathrm{sec}$ 에 비해 다소 낮은
속도로 측정되었는데 이는 중량체와 Tower 사이의 마찰 등의 영향으로 판단된다.

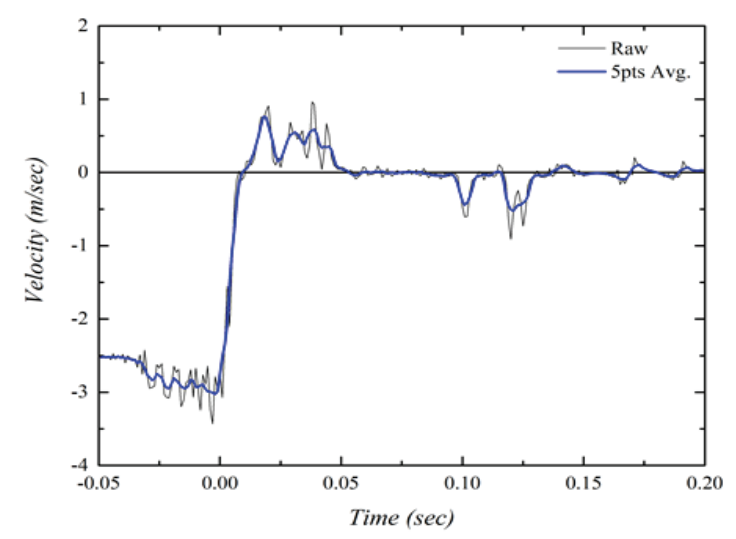

Fig. 9. Drop Velocity of Weight (CASE 1)

Fig. 10은 측면에서 촬영한 고속카메라 영상분석을 통해 도출한 DCP 단부(충돌지점 쪽)의 수직 방향 변위를 나타낸 것으로 충돌 직후 최대변위는 $11.66 \mathrm{~mm}$, 이후 잔류변위는 $6.89 \mathrm{~mm}$ 로 나타났다.

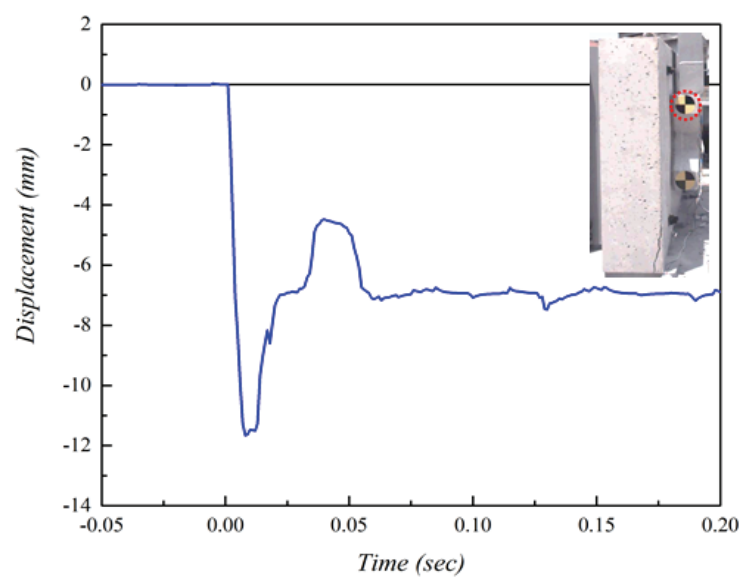

Fig. 10. Displacement of DCP (CASE 1)

\subsubsection{CASE 2 (\#2-2)}

실측된 낙하 높이는 $0.499 \mathrm{~m}$ 로 DCP 실험체의 중앙부에 작용시킨 충돌에너지는 $3.51 \mathrm{~kJ}$ 이다. 좌측 앵커부 표면 일부에 균열이 발생되었으며, DCP 패널 전반에 걸쳐 TCL 층과의 접합부 사이에 약 $1 \mathrm{~mm}$ 의 미세한 분리 현상이 발생되었다(Fig. 11). 그러나 DCP 패널을 지지하는 앵커는 모두 건전한 상태로 $\mathrm{DCP}$ 의 기능 - 성능을 상실한 상태는 아니다.

Fig. 12는 시간에 따른 중량체의 낙하속도를 고속카메라 영상분석을 통해 나타낸 것으로 $\mathrm{DCP}$ 와 충돌 직전의 속도가 $3.01 \mathrm{~m} / \mathrm{sec}$ 로 측정되었다. 역시 실측 낙하 높이 $0.499 \mathrm{~m}$ 에 따른 이론 속도 $3.13 \mathrm{~m} / \mathrm{sec}$ 보다 다소 작게 나타났다. 


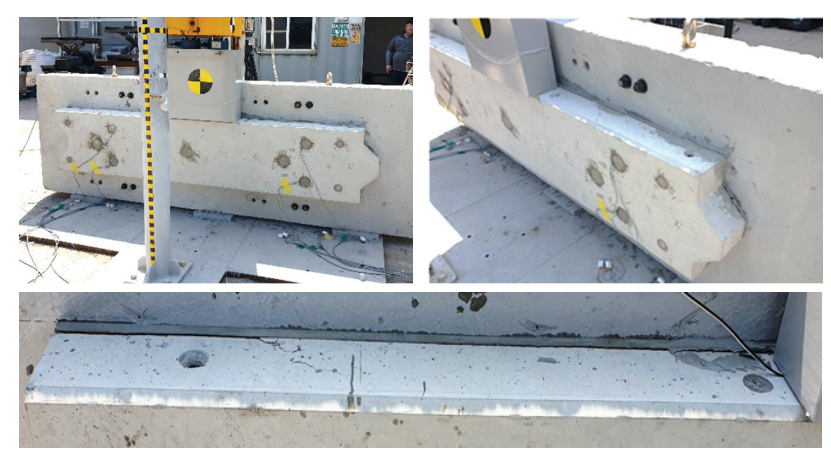

Fig. 11. Condition after Test (CASE 2)

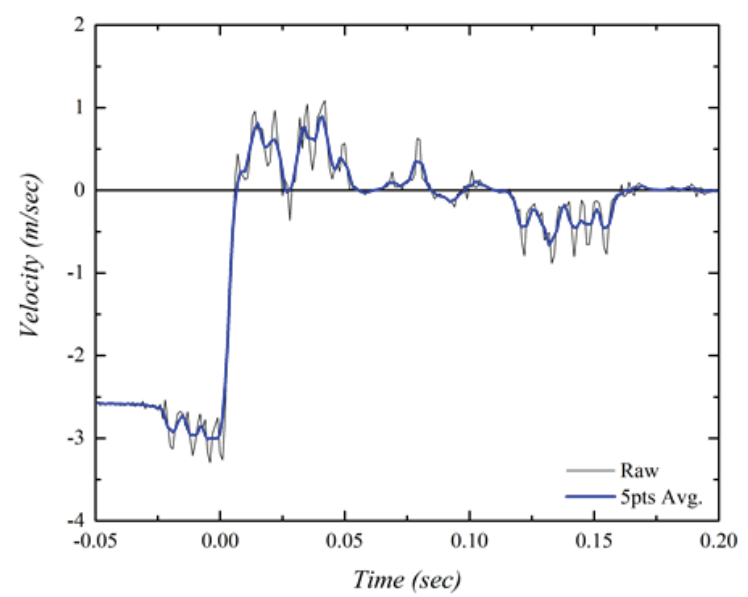

Fig. 12. Drop Velocity of Weight (CASE 2)

Fig. 13은 측면에서 촬영한 고속카메라 영상을 통해 도출 한 DCP 단부의 수직 방향 변위를 나타낸 것으로 충돌 직후 최대변위는 $3.98 \mathrm{~mm}$, 이후 잔류변위는 $0.01 \mathrm{~mm}$ 로 나타났다. CASE 1과 비교하여 DCP 패널 중앙부 충돌 시 양측 앵커의 충분한 하중 분담 효과로 잔류변위가 발생하지 않은 것으로 판단된다.

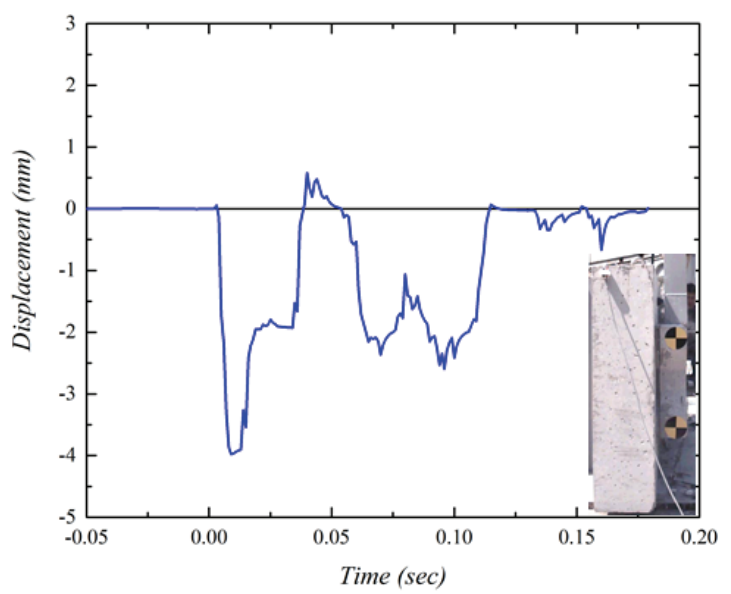

Fig. 13. Displacement of DCP (CASE 2)

\subsubsection{CASE 3 (\#2-3)}

CASE 2 실험 후에 동일한 실험체(\#2) 및 충돌지점에 낙하 높이만 달리하여 누적 충돌에너지를 가하였다. 실측된 낙하 높이는 $1.003 \mathrm{~m}$ 로 DCP 실험체의 중앙부에 작용시킨 충돌에너지는 $7.06 \mathrm{~kJ}$ 이며 누적된 충돌에너지는 $10.57 \mathrm{~kJ}$ 이 다. 좌, 우측 앵커 피복부에 파손이 발생되었으며, TCL층과 $\mathrm{DCP}$ 패널 접합부 사이에 약 $2.5 \sim 2.8 \mathrm{~mm}$ 의 분리 현상이 상대적으로 크게 발생되었다(Fig. 14).
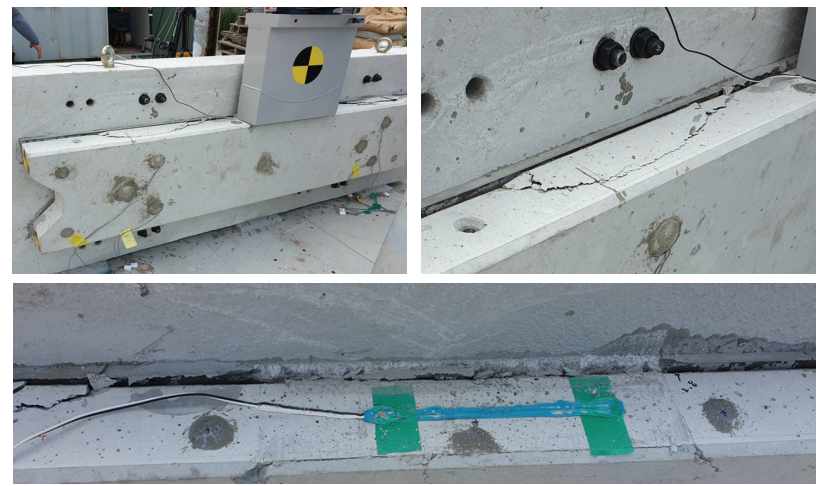

Fig. 14. Condition after Test (CASE 3)

$\mathrm{DCP}$ 와 충돌 직전의 이론 속도와 고속카메라 영상분석을 통한 속도는 각각 $4.44,4.35 \mathrm{~m} / \mathrm{sec}$ 로 나타났으며, DCP 단부 의 수직 방향 최대변위는 $13.61 \mathrm{~mm}$, 잔류변위 $10.09 \mathrm{~mm}$ 로 나타났다(Fig. 15).

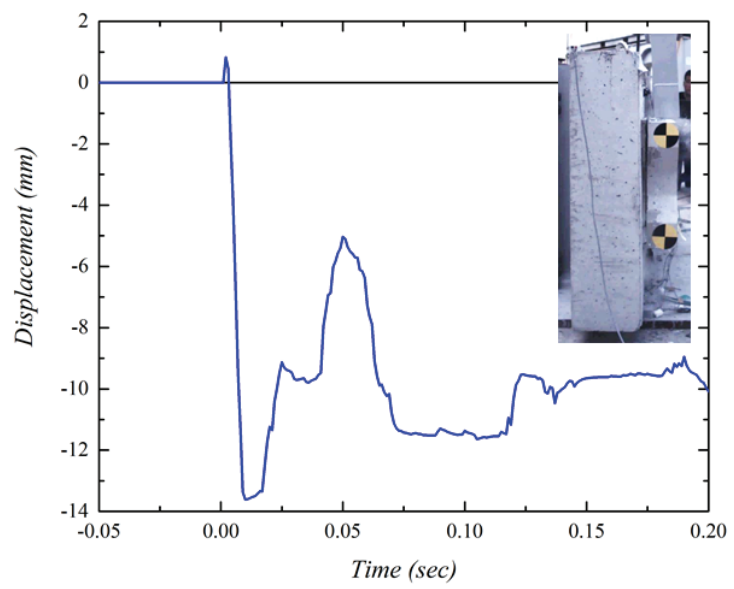

Fig. 15. Displacement of DCP (CASE 3)

\subsubsection{CASE 4 (\#2-4)}

CASE 3 실험 이후 동일한 실험체(\#2) 및 충돌지점에 낙하 높이만 달리하여 누적 충돌에너지를 가하였다. 실측된 낙하 높이는 $0.506 \mathrm{~m}$ 로 DCP 실험체의 중앙부에 작용시킨 충돌에너지는 $3.56 \mathrm{~kJ}$ 이며 총 누적된 충돌에너지는 14.13 $\mathrm{kJ}$ 이다. 좌, 우측 앵커 피복부에 파손이 더욱 크게 발생되었으 며 $\mathrm{DCP}$ 의 철근과 앵커가 노출되었다(Fig. 16). 

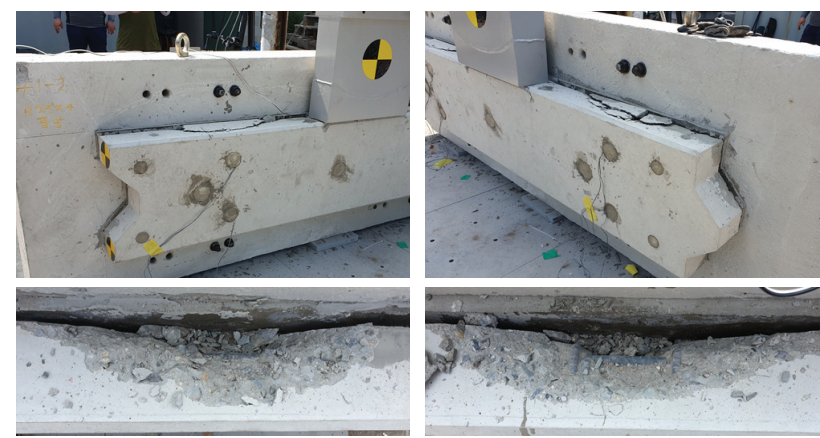

Fig. 16. Condition after Test (CASE 4)

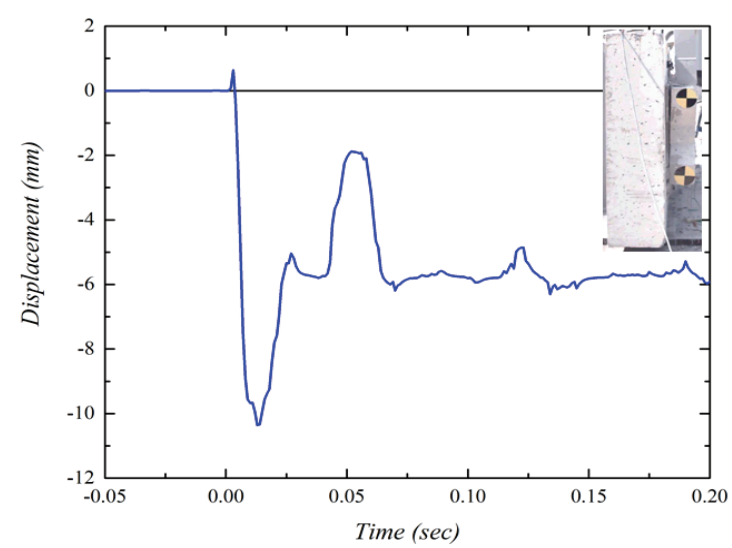

Fig. 17. Displacement of DCP (CASE 4)

$\mathrm{DCP}$ 와 충돌 직전의 이론 속도와 고속카메라 영상분석을 통한 속도는 각각 $3.15,3.04 \mathrm{~m} / \mathrm{sec}$ 로 나타났으며, DCP 단부의 수직 방향 최대변위는 $10.35 \mathrm{~mm}$, 잔류변위 $5.91 \mathrm{~mm}$ 로 나타났다 (Fig. 17). 이때 초기 상태는 CASE 3 실험 이후(누적 잔류변위 $10.10 \mathrm{~mm}$ )가 되므로 최종 잔류변위는 $16.01 \mathrm{~mm}$ 로 볼 수 있다. $\mathrm{DCP}$ 패널을 지지하는 앵커 단면이 일부 항복한 상태로 강도 성능은 상실하였다고 볼 수 있으나, DCP 패널이 TCL층으로부 터 분리된 정도의 상태는 아니기 때문에 탈선된 차륜을 제어하 는 $\mathrm{DCP}$ 로서의 기능은 발휘할 수 있는 상태로 볼 수 있다.

\subsubsection{CASE 5 (\#3-5)}

CASE 5의 실측된 낙하 높이는 $1.007 \mathrm{~m}$ 로 DCP 실험체의 중앙부에 작용시킨 충돌에너지는 $7.09 \mathrm{~kJ}$ 이다. 좌측 앵커부 표면 일부에 균열이 발생하였고, 우측 앵커부에는 균열 이상 의 파손이 발생하였다(Fig. 18).
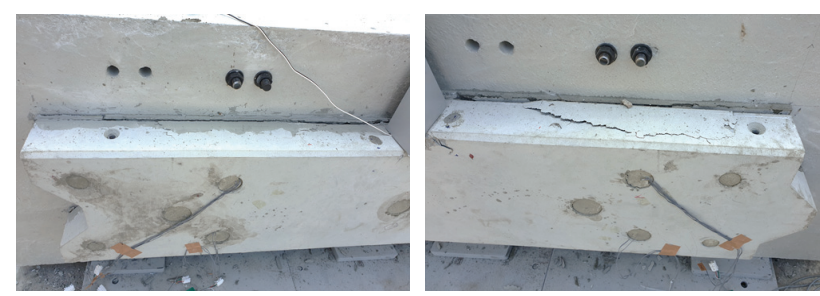

Fig. 18. Condition after Test (CASE 5)
$\mathrm{DCP}$ 와 충돌 직전의 이론 속도와 고속카메라 영상분석을 통한 속도는 각각 $4.44,4.37 \mathrm{~m} / \mathrm{sec}$ 로 나타났으며, DCP 단부의 수직 방향 최대변위는 $6.19 \mathrm{~mm}$, 잔류변위 $5.59 \mathrm{~mm}$ 로 나타났 다(Fig. 19). 앵커는 모두 건전한 상태로 DCP의 기능 - 성능에 는 큰 문제가 없는 상태를 유지하였다.

CASE 3(낙하 높이 $1.003 \mathrm{~m}$, 충돌에너지 $7.06 \mathrm{~kJ}$ )과 유사한 충돌 후 상태를 나타내었으나 CASE 3 의 경우는 $3.51 \mathrm{~kJ}$ 의 충돌에너지가 가해진 초기 상태에서 2차 충돌시킨 것으로(누 적 $10.57 \mathrm{~kJ}$ ) 잔류변위에서 $4.51 \mathrm{~mm}$ 의 차이가 발생하였다.

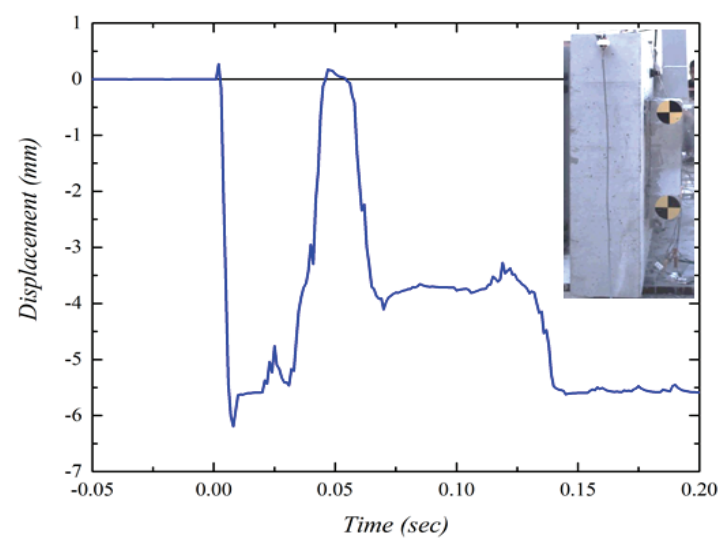

Fig. 19. Displacement of DCP (CASE 5)

\subsubsection{CASE 6 (\#3-6)}

CASE 5 실험 후 동일한 실험체(\#3) 및 충돌지점에 낙하 높이 또한 유사하게 하여 누적 충돌에너지를 가하였다. 실측 된 낙하 높이는 $1.009 \mathrm{~m}$ 로 DCP 실험체의 중앙부에 작용시킨 충돌에너지는 $7.11 \mathrm{~kJ}$ 이며 누적된 충돌에너지는 $14.20 \mathrm{~kJ}$ 이 다. 좌, 우측 앵커 피복부에 파손이 더욱 크게 발생되었으며 $\mathrm{DCP}$ 의 철근과 앵커가 노출되었다(Fig. 20). DCP 패널을 지지하는 앵커 단면이 일부 항복한 상태로 강도 성능은 상실하였다고 볼 수 있으나, $\mathrm{DCP}$ 패널이 TCL층으로부터 분리된 정도의 상태는 아니기 때문에 탈선된 차륜을 제어하 는 $\mathrm{DCP}$ 로서의 기능은 발휘할 수 있는 상태로 볼 수 있다. 이는 누적 충돌에너지가 거의 동일한 CASE $4(14.13 \mathrm{~kJ})$ 의 결과와 유사한 충돌 후 상태를 나타내었다.
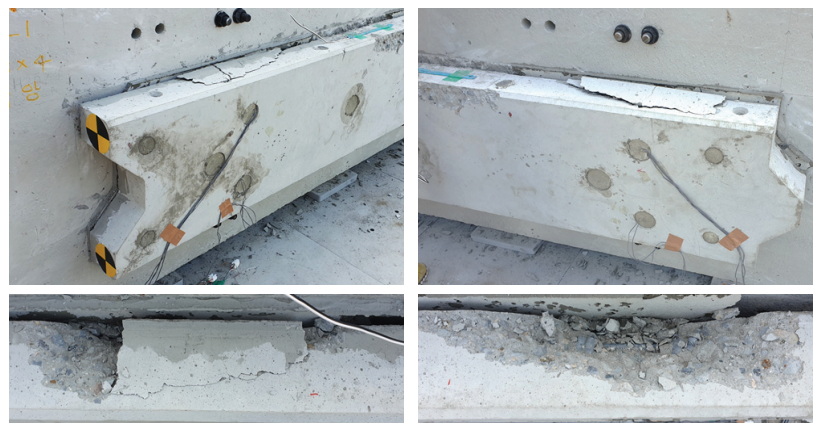

Fig. 20. Condition after Test (CASE 6) 
$\mathrm{DCP}$ 와 충돌 직전의 이론 속도와 고속카메라 영상분석을 통한 속도는 각각 $4.45,4.38 \mathrm{~m} / \mathrm{sec}$ 로 나타났으며, DCP 단부의 수직 방향 최대변위는 $13.30 \mathrm{~mm}$, 잔류변위 $9.27 \mathrm{~mm}$ 로 나타났 다(Fig. 21). 이때 초기 상태는 CASE 5 실험 이후(잔류변위 $5.59 \mathrm{~mm}$ )가 되므로 최종 잔류변위는 $14.86 \mathrm{~mm}$ 로 볼 수 있다.

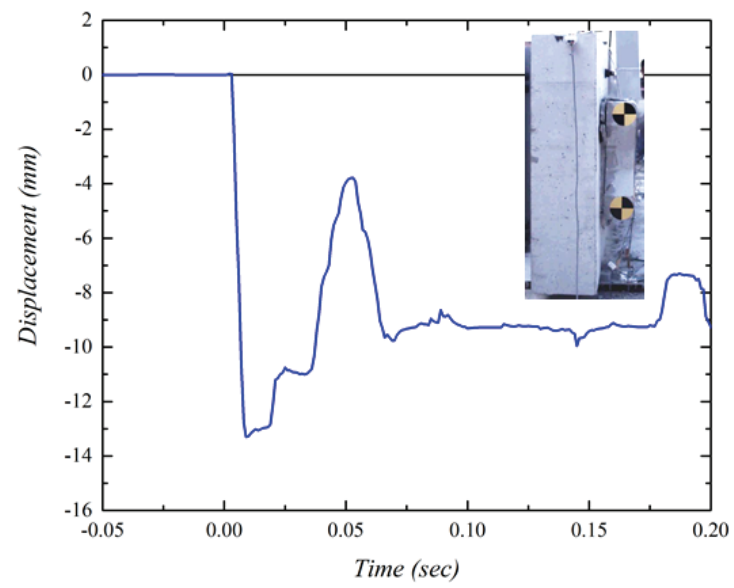

Fig. 21. Displacement of DCP (CASE 6)

CASE 6의 누적 충돌에너지 $(14.20 \mathrm{~kJ})$ 와 거의 동일한 누적 충돌에너지 상태인 CASE $4(14.13 \mathrm{~kJ})$ 의 결과를 비교하면, 충돌 후 파손상태가 유사하고 최종 잔류변위 또한 $1.15 \mathrm{~mm}$ (16.01-14.86)의 차이가 발생하여 매우 유사한 상태로 볼 수 있다. 약간의 차이는 실험체(\#2,\#3) 제작 - 시공상의 차이 영향도 있겠지만 CASE 4의 경우 3 차에 걸친 누적 충돌로 충돌 횟수의 영향도 포함될 수 있다고 판단된다.

\subsubsection{CASE 7 (\#3-7)}

CASE 7은 CASE 6 실험 후 동일한 실험체(\#3) 및 충돌지점 에 상대적으로 큰 누적 충돌에너지를 가하였다. 실측된 낙하 높이는 $2.138 \mathrm{~m}$ 로 DCP 실험체의 중앙부에 작용시킨 충돌에 너지는 $15.06 \mathrm{~kJ}$ 이며 총 누적된 충돌에너지는 $29.26 \mathrm{~kJ}$ 이다. $\mathrm{TCL}$ 층에 고정된 $\mathrm{DCP}$ 패널이 앵커와 완전히 분리되어 $\mathrm{DCP}$ 목적상 탈선된 차륜을 제어하는 일탈방호성능이 상실되었 다(Fig. 22).

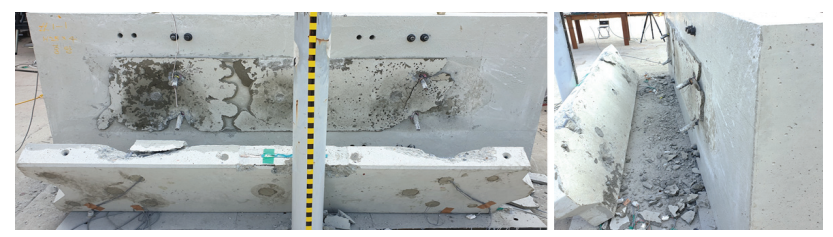

Fig. 22. Condition after Test (CASE 7)

$\mathrm{DCP}$ 와 충돌 직전의 이론 속도와 고속카메라 영상분석을 통한 속도는 각각 $6.48,6.29 \mathrm{~m} / \mathrm{sec}$ 로 나타났다. Fig. 23은 시간에 따른 DCP 단부의 수직 방향 변위를 나타낸다.

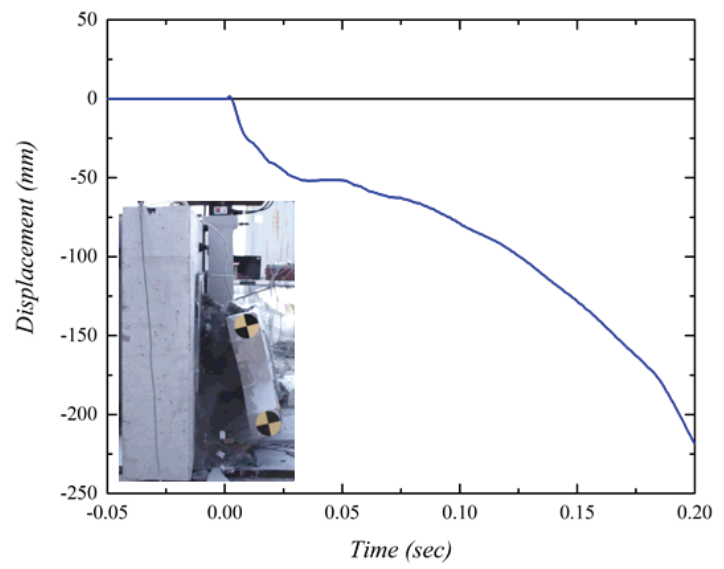

Fig. 23. Displacement of DCP (CASE 7)

\section{4. 내충격성 평가}

\section{1 시뮬레이션을 통한 DCP 충격에너지}

선행연구(Song et al., 2019a, 2019b)에 의해 개발된 열차 탈선-충돌 시뮬레이션 모델을 이용하여, $300 \mathrm{~km} / \mathrm{h}$ 속도로 주행하는 열차가 최소 곡선반경 $3,500 \mathrm{~m}$ 이고 궤간 내 DCP가 설치된 궤도를 주행하다 탈선하는 시뮬레이션을 수행하였다 (Fig. 24). 충돌해석 분야에 특화된 범용소프트웨어 LS-DYNA (LSTC, 2007)를 사용하였으며, 열차 모델의 제원 및 물성은 KTX 열차의 차륜 및 대차시스템, 중량 중심 관성모멘트 등을 준용하였고(Hong, 2006), 해석 Runtime의 효율성을 고려하여 동력차, 동력객차, 객차 3 량을 모델링하였다. 콘크리트 침목 및 $\mathrm{DCP}$ 의 재료적 특성은 손상을 효과적으로 고려할 수 있는 Continuous Surface Cap Material (CSCM)을 사용하였다.

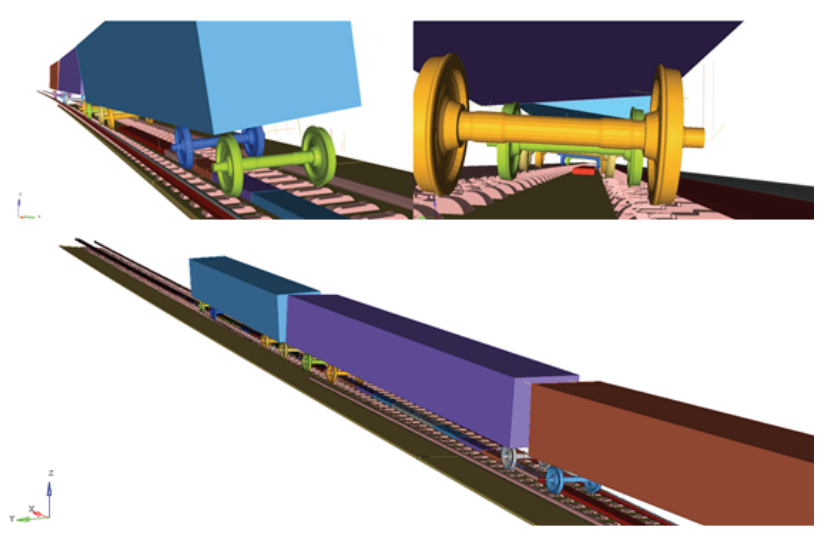

Fig. 24. Derailment Simulation of High-speed Train

탈선된 열차의 차륜들은 궤간 내 DCP와 연속적으로 충돌 하며 진행하고, 차륜별로 충돌 시점과 충돌 지점, 차륜과 $\mathrm{DCP}$ 측면부의 접촉 거동 등이 다르지만 전체적으로 차량의 진행이 $\mathrm{DCP}$ 에 의해 제어되어 곡선 궤도 외측으로 과도하게 벗어나지 않고 궤도 영역 내로 진행됨을 확인할 수 있었다. 
이러한 시뮬레이션 결과에서 DCP 패널당 발생되는 충돌 에 의한 내부에너지(Internal Energy)를 도출하여 DCP 실험 체의 낙하충격실험에 의한 결과와 비교하고자 하였다.

Fig. 25는 시뮬레이션 모델의 DCP 패널별로 충돌에 의해 누적된 내부에너지를 나타내었다. 한 패널에는 탈선열차의 차륜 들(3량-10개) 중 1 개의 차륜만 충돌할 수도 있으며 여러 개의 차륜이 충돌할 수도 있다. 1 10번 DCP의 경우 차륜당 최대 $0.90 \mathrm{~kJ}$, 평균 $0.12 \mathrm{~kJ}$ 의 내부에너지를 받았으며 $11 \sim 15$ 번 DCP의 경우 차륜당 최대 $3.28 \mathrm{~kJ}$, 평균 $1.74 \mathrm{~kJ}$ 의 내부에너지를 받았다. 이는 탈선 초기에 열차 객차 간 연결 효과에 의해 적은 충돌에너 지의 영향을 받다가 연결 효과가 없어지는 가장 후미의 열차는 탈선 시 상대적으로 큰 충돌에너지의 영향(열차의 수직 방향 축에 대한 회전력-Yawing)을 받기 때문이다. 객차 1 량당 약 5 개의 DCP 패널에 충돌하는 경향으로 나타나 실제 KTX 열차 20 량을 고려했을 때 최대 충돌에너지를 받는 DCP 패널은 최초 탈선지점으로부터 95 100번째일 것으로 추정된다.

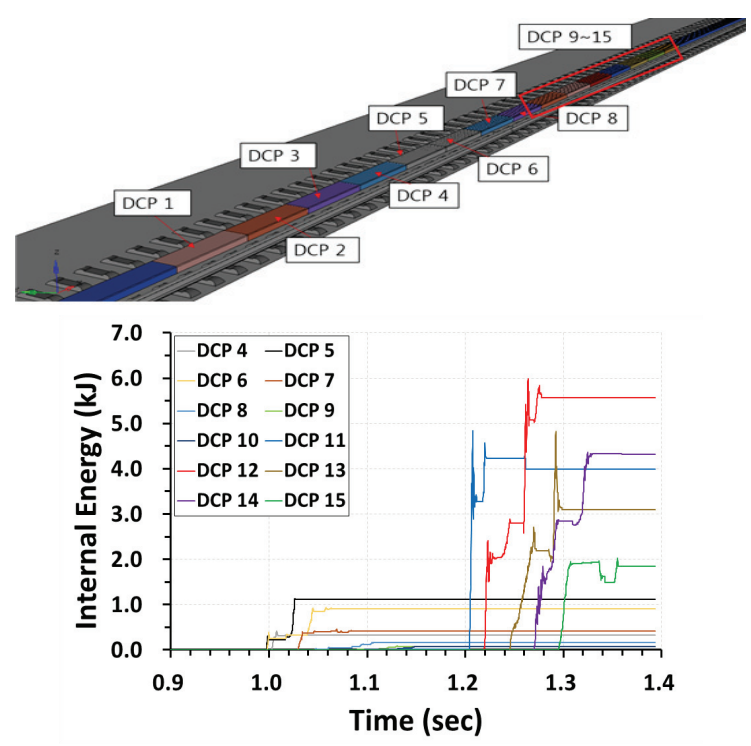

Fig. 25. Internal Energy of DCP Panels

본 시뮬레이션에서 차륜당 최대로 발생된 내부에너지는 11 번 패널에서 $3.28 \mathrm{~kJ}$ 이었으며, 최대 누적된 내부에너지는
12 번 패널에서 4 개의 차륜이 충돌하여 $5.57 \mathrm{~kJ}$ 로 나타났다 (Table 2).

Table 2. Internal Energy of DCP Panels

\begin{tabular}{c|c|c}
\hline DCP No. & $\begin{array}{c}\text { Max. Internal Energy } \\
\text { per a Wheel }(\mathrm{kJ})\end{array}$ & $\begin{array}{c}\text { Cumulative } \\
\text { Internal Energy }(\mathrm{kJ})\end{array}$ \\
\hline DCP 4 & $0.31(1 \mathrm{st} / 2)$ & 0.32 \\
\hline DCP 5 & $0.90(2 \mathrm{nd} / 2)$ & 1.12 \\
\hline DCP 6 & $0.53(3 \mathrm{rd} / 5)$ & 0.91 \\
\hline DCP 7 & $0.37(1 \mathrm{st} / 3)$ & 0.42 \\
\hline DCP 8 & $0.05(4 \mathrm{th} / 5)$ & 0.16 \\
\hline DCP 9 & $0.04(2 \mathrm{nd} / 3)$ & 0.08 \\
\hline DCP 10 & $0.03(5 \mathrm{th} / 5)$ & 0.08 \\
\hline DCP 11 & $3.28(1 \mathrm{st} / 2)$ & 4.30 \\
\hline DCP 12 & $2.28(3 \mathrm{rd} / 4)$ & 5.57 \\
\hline DCP 13 & $2.18(1 \mathrm{st} / 2)$ & 3.09 \\
\hline DCP 14 & $2.84(1 \mathrm{st} / 2)$ & 4.31 \\
\hline DCP 15 & $1.85(1 \mathrm{st} / 1)$ & 1.85 \\
\hline
\end{tabular}

\section{2 궤간 내 $\mathrm{DCP}$ 의 내충격성 평가}

Table 3에 궤간 내 DCP 실험체의 낙하충격실험 결과를 CASE 별로 정리하여 나타내었다. 고속열차 탈선-충돌 시뮬 레이션 결과와 비교하였을 때, 1 개의 차륜이 DCP 패널에 작용될 수 있는 최대 충돌에너지는 $3.28 \mathrm{~kJ}$ 로, CASE 2 (\#2-2) 의 결과로부터 표면 균열 정도의 손상상태가 예상되며 DCP 패널을 횡방향으로 지지하는 앵커가 모두 건전한 상태로 일탈방호성능을 충분히 확보할 수 있다.

또한, 여러 개의 차륜들이 한 패널에 연속 충돌하여 누적될 수 있는 최대 충돌에너지는 $5.57 \mathrm{~kJ}$ 로, CASE 3 (\#2-3)과 CASE 5 (\#3-5)의 결과로부터 7 10 kJ의 누적 충돌에너지에 서는 표면 파손 손상상태가 됨을 미루어보아 표면 파손 또는 균열 정도의 손상상태가 예상된다. DCP 패널의 잔류변 위는 약 $5 \mathrm{~mm}$ 이하로 예상되어 앵커 또한 모두 건전한 상태로 DCP로서의 기능 - 성능에는 큰 문제가 없는 상태를 유지할 수 있다.

Table 3. Test Summary

\begin{tabular}{|c|c|c|c|c|c|c|c|c|c|}
\hline \multirow{2}{*}{ Case No. } & \multirow{2}{*}{$\begin{array}{c}\text { Impact } \\
\text { Point }\end{array}$} & \multirow{2}{*}{$\begin{array}{c}\text { Drop } \\
\text { Height }(\mathrm{m})\end{array}$} & \multicolumn{2}{|c|}{ Impact Velocity $(\mathrm{m} / \mathrm{s})$} & \multicolumn{2}{|c|}{ Impact Energy $(\mathrm{kJ})$} & \multicolumn{2}{|c|}{ Displacement $(\mathrm{mm})$} & \multirow{2}{*}{ Damage Condition } \\
\hline & & & Theory & Measure & Case & Cumulative & Case & Cumulative & \\
\hline$\# 1-1 \quad(1)$ & Anchor & 0.508 & 3.16 & 3.02 & 3.58 & - & 6.89 & - & Surface Crack \\
\hline$\# 2-2$ (1) & \multirow{3}{*}{ Center } & 0.499 & 3.13 & 3.01 & 3.51 & 3.51 & 0.01 & 0.01 & Surface Crack \\
\hline \#2-3 (2) & & 1.003 & 4.44 & 4.35 & 7.06 & 10.57 & 10.09 & 10.10 & Surface Breakage \\
\hline$\# 2-4$ (3) & & 0.506 & 3.15 & 3.04 & 3.56 & 14.13 & 5.91 & 16.01 & Rebar Exposure \\
\hline$\# 3-5$ (1) & \multirow{3}{*}{ Center } & 1.007 & 4.44 & 4.37 & 7.09 & 7.09 & 5.59 & 5.59 & Surface Breakage \\
\hline$\# 3-6(2)$ & & 1.009 & 4.45 & 4.38 & 7.11 & 14.20 & 9.27 & 14.86 & Rebar Exposure \\
\hline \#3-7 (3) & & 2.138 & 6.48 & 6.29 & 15.06 & 29.26 & - & - & DCP Detached \\
\hline
\end{tabular}


단, DCP 패널의 충돌지점에 따라 손상 정도에 영향이 있을 수 있는데, CASE 1 (\#1-1)의 결과를 봤을 때 한쪽 앵커부 에 최대 충돌에너지로 충돌할 경우 약 $6 \mathrm{~mm}$ 정도의 잔류변위 가 예상된다. 그러나 DCP의 기능적 측면에서는 문제가 없는 상태였으며 지지 앵커의 소성변형이 아닌 앵커부 그라우트 (무수축 모르타르)에 의한 변형으로 나타나 시공성을 개선한 다면 $\mathrm{DCP}$ 의 강도 성능에도 문제가 없을 것으로 판단된다. 또한, 실제는 탈선된 차륜들이 여러 차례 $\mathrm{DCP}$ 와 충돌할 때 충돌지점과 차륜과의 접촉면적이 상이하므로, 낙하충격 실험에서 설정한 한 지점에 최대 접촉면적으로 누적하여 재하한 실험조건은 실제 현상보다 상당히 보수적으로 평가될 수 있는 조건이다. 이에 따른 사항들을 고려했을 때 고속열차 탈선 시 피해 최소화를 위해 개발된 궤간 내 $\mathrm{DCP}$ 의 내충격성 은 충분한 것으로 판단된다.

\section{5. 결 론}

본 논문에서는 고속열차의 탈선 시 피해 최소화를 위해 개발된 교량상 콘크리트 궤도용 궤간 내 $\mathrm{DCP}$ 의 내충격성을 평가하기 위한 연구를 수행하여 다음과 같은 결론을 도출하 였다.

DCP 패널 실험체의 낙하충격실험을 통해 충돌에너지 약 $3.5 \mathrm{~kJ}$ 에서 표면 균열 정도의 손상상태가 발생하며(잔류변 위 $0.01 \mathrm{~mm})$, 약 7 10 kJ로 누적된 충돌에너지에서는 표면 파손 손상상태가 발생하였다(잔류변위 $5.5 ~ 10.1 \mathrm{~mm}$ ). 이때 콘크리트 궤도 TCL층에 DCP 패널을 지지하는 앵커가 모두 건전한 상태로 $\mathrm{DCP}$ 로서의 기능 - 성능을 발휘할 수 있는 상태로 평가되었다.

약 $14 \mathrm{~kJ}$ 의 누적 충돌에너지에서는 철근과 앵커가 노출되 는 정도의 손상상태를 보이며, 앵커 단면이 일부 항복한 상태로 강도 성능은 상실하였다고 볼 수 있으나 DCP 패널이 $\mathrm{TCL}$ 층으로부터 분리된 상태는 아니기 때문에 탈선된 차륜을 제어하는 $\mathrm{DCP}$ 로서의 기능적 측면에서는 성능을 유지할 수 있는 상태로 평가되었다. $29.26 \mathrm{~kJ}$ 의 누적 충돌에너지에서는 $\mathrm{TCL}$ 층에 고정된 $\mathrm{DCP}$ 패널이 앵커와 완전히 분리되어 $\mathrm{DCP}$ 목적상 탈선된 차륜을 제어하는 일탈방호성능이 상실되었다.

검증된 고속열차 탈선-충돌 시뮬레이션 기법을 통해 DCP 패널당 차륜이 1 5회 충돌할 수 있고 차륜당 최대로 발생된 내부에너지는 $3.28 \mathrm{~kJ}$, 최대 누적 내부에너지(4회 충돌)는 $5.57 \mathrm{~kJ}$ 로 산정되어, 낙하충격실험에 의한 결과 $($ 약 $3.5 \mathrm{~kJ}$ 의 순간 최대 에너지 및 약 $14 \mathrm{~kJ}$ 의 누적 에너지에서 성능 유지)와 비교했을 때 개발된 궤간 내 $\mathrm{DCP}$ 의 내충격성이 확보되었다고 평가되었다.

\section{감사의 글}

본 연구는 국토교통부 철도기술연구사업의 연구비지원
(19RTRP-B122273-04)에 의해 수행되었습니다.

\section{References}

Bae, H.U. (2015). Advanced design concept of derailment containment provisions using collision simulation after train derailment. Ph.D. dissertation, Chungnam National University.

Bae, H.U., Yun, K.M., and Lim, N.H. (2018a). Containment capacity and estimation of crashworthiness of derailment containment walls against high-speed train. Proc. Inst. Mech. Eng. Part F: J. Rail Rapid Transit, Vol. 232, No. 3, pp. 680-696.

Bae, H.U., Yun, K.M., Moon, J., and Lim, N.H. (2018b). Impact force evaluation of the derailment containment wall for high-speed train through a collision simulation. Adv. Civ. Eng., Vol. 2018, Article ID 2626905. doi:10.1155/2018/2626905

Booz Allen Hamilton Inc. (2004). Report on the findings of: Current practice and effectiveness of derailment containment provisions on high speed lines. Issue 1, Ref: R00673, HSL-Zuid Organisation, Zoetermeer, Netherlands.

Hong, T.D. (2006). A study on the improvement of KTX bogie instability. Master's thesis, University of Seoul.

Kim, J.H., Bae, H.U., Kim, J.W., Song, I.H., Lee, C.O., and Lim, N.H. (2018). Post-derailment behavior of casting bogie by full scale test. Journal of the Korean Society for Railway, Vol. 21, No. 8, pp. 815-829.

Kim, J.H., Yi, N.H., Kang, Y.S., and Song, M. (2019). Experiment study on structural performance of concrete derailment containment provision (DCP). J. Korean Soc. Hazard Mitig., Vol. 19, No. 4, pp. 37-43.

Korea Agency for Infrastructure Technology Advancement (KAIA). (2020). Research for development and design criteria of derailment containment provisions for railway vehicle. Project No. 19RTRP-B12227304, Ministry of Land, Infrastructure and Transport.

Korea Rail Network Authority (KR). (2016). Track maintenance guidelines.

Korea Rail Network Authority (KR). (2017). Railway design guideline and handbook - Subsidiary and safety facilities for main lined. KR C-02060.

Livermore Software Technology Corporation (LSTC). (2007). LS-DYNA theory manual. Version 971, LSTC, CA, USA. 
Railroad Safety Act (2018).

Song, I.H., Kim, J.W., Koo, J.S., and Lim, N.H. (2019a). Modeling and simulation of collision-causing derailment to design the derailment containment provision using a simplified vehicle model. Appl. Sci., Vol. 10, No. 1, 118. doi:10.3390/app10010118 Song, I.H., Kim, J.W., Koo, J.S., Bae, H.U., and Lim, N.H. (2019b). Simplified vehicle modeling technique for design of derailment containment provisions (DCP). J. Korean Soc. Railw., Vol. 22, No. 7, pp. 527-537.
Yi, N.H., Kim, J.H., and Kang, Y.S. (2018). Analytical behavior of concrete derailment containment provision (DCP) according to train impact loading. Journal of the Korea Academia-Industrial Cooperation Society, Vol. 19, No. 11, pp. 604-613.

\begin{tabular}{l|l} 
Received & September 14, 2020 \\
\hline Revised & September 15, 2020 \\
\hline Accepted & September 23, 2020
\end{tabular}

